\title{
Bakens op die weg van die evangelienavorsing, met besondere verwysing na die metodes van uitleg
}

JJ Engelbrecht

\section{INLEIDING}

Daar is mense wat vandag nog die evangelies lees asof dit noukeurige verslae is van wat Jesus presies in bepaalde situasies gesê en gedoen het. Sonder om verkleinerend te wees, sou' $n$ mens van so' $n$ standpunt kon sê: "Sanctitas simplicitas", dit is: salige eenvoud!

Wie noukeurig let op wat in die evangelies te lees is, byvoorbeeld die berigte oor die versoekinge van Jesus deur die duiwel en dié oor die opstanding van Jesus uit die dode, en krities daaroor nadink, kom vroeër of later agter dat wat ons die "sanctitas simplicitas"standpunt genoem het, onhoudbaar is. Dit plaas die leser immers voor onoorkomelike probleme. Hierdie probleme duik op nie omdat die navorser noodwendig ' $n$ ongelowige of ' $n$ rasionalis of ' $n$ spotter is nie, maar om 'n ander rede: 'n Gelowige ondersoeker kom voor die probleme te staan onder andere omdat hy ook met die verstand wat ons goeie God aan hom gegee het, wil probeer vasstel wát Hy deur middel van die evangelies aan ons wil bekend maak! Juis ómdat hy glo dat die Skrif waarvan die evangelies deel uitmaak, deur God aan ons gegee is as hoogste norm vir ons geloof en leer en lewe, moet alle beskikbare hulpmiddele, dus ook die menslike verstand, ingespan word om so noukeurig as moontlik te probeer vasstel wat hierdie tekste vir ons sê.

Dit is wel so dat die gelowige navorser in sy wetenskaplike worsteling om by die saak uit te kom, in sekere opsigte saamloop met hulle vir wie dit in die eerste plek bloot om historiese kennis gaan, maar dit beteken nie dat die geloof afhanklik gemaak word van die veranderinge en onsekerheid van die historiese of literêre ondersoek nie (vgl. Bornkamm 1968:5). Tereg merk Du Toit (1980a:276) op dat die onttrekking van die evangelies aan die historiese ondersoek geen oplossing is nie, maar 'n teken van swak vertroue. Daar moet egter, so sê hy, in alle skerpte geëis word dat die ondersoeker wetenskaplik suiwer en korrek te werk sal gaan.

Die nie-teoloog wat 'n Christen is, neem die Bybel in die hand en lees daarin met die verwagting dat hy met God in aanraking sal kom deur te luister na die boodskap van die Bybel. Die gelowige NuweTestamentikus doen dieselfde, maar probeer die boodskap hoor deur die geskrewe dokumente waaruit die Nuwe Testament bestaan, 
sover as moontlik in hul historiese verband te plaas en hulle te analiseer met alle middele wat die taal-, literatuur- en geskiedeniswetenskap tot sy beskikking stel. Die verskil tussen genoemde twee benaderings kan lei tot ' $n$ vrugbare konfrontasie wat tot voordeel van sowel die Nuwe-Testamentiese wetenskap as die geloof kan strek (vgl. De Jonge \& Van Duyne 1982:9-10).

'n Wesenlike probleem waarmee die Nuwe-Testamentikus worstel, is die vraag na die verhouding tussen navorsing op sy vakgebied en die Dogmatiek. Onder andere in die Nederduitsch Hervormde Kerk van Afrika is daar die bykomende saak van die verhouding tussen wetenskaplike navorsing op die terrein van die Bybel-wetenskappe en die bedienaar van die Woord se binding aan die ondertekeningsformulier. Wat staan 'n Nuwe-Testamentikus te doen as hy tot die gevolgtrekking sou kom dat een of ander aspek van ' $n$ kerklike belydenisskrif eksegeties onhoudbaar is?

\section{VANAF DIE TWEEDE EEU TOT EN MET DIE REFORMASIE}

Vanaf die vroegste kerkvaders kom daar belangrike historiese stof èn talle relevante insigte voor in kommentare op Nuwe-Testamentiese geskrifte. Die eksegese is destyds egter nie bewustelik met historiese oogmerke onderneem nie. Van 'n wetenskaplike bestudering van die Nuwe Testament of van ' $n$ historiese benadering van die Christendom in die eerste of tweede eeu, was daar geen sprake vóór die tyd van die Verligting nie. (Die Verligting was die 18de-eeuse invloedryke geestesstroming in Europa. Volgens dié geestesstroming is dit korrek dat 'n grenslose vertroue in die redelikheid van die wêreld en van die mens gestel word; daarby is daar gestreef na die veredeling van die mens.)

Die enigste blyke van 'n historiese belangstelling in die eerste eeue van die kerkgeskiedenis was Marsion se inleidings of proloë tot bepaalde geskrifte wat vandag deel van die Nuwe Testament uitmaak, asook die vraag na die outeurskap van bepaalde geskrifte. Laasgenoemde vraag het aktueel geraak by die kerklike worsteling om die kanon van die Nuwe Testament vas te stel. Origenes (ong 185-254) gaan verder en stel kritiese vrae oor die korrektheid van 'n bepaalde tradisie met betrekking tot outeurskap, byvoorbeeld die outeurskap by Hebreërs. Hy stel die vrae op stilistiese gronde, maar kom nie tot besliste gevolgtrekkings nie.

Origens se leerling, naamlik Dionysius van Aleksandrië (biskop 245-265) kom later met egte historiese kritiek op grond van taalkundige en stilistiese verskille, en verwerp die tradisionele opvattinge oor wie die Johannesevangelie en -briewe en die boek Openbaring geskryf het. Hy handhaaf beslis die geldigheid van die historiese kritiek. 
Hoewel die Middeleeuse kerk wel iets geweet het van die outeursvrae en tradisies oor ontstaansituasies van sommige Nuwe-Testamentiese geskrifte, is hierdie vrae eers teen die einde van die Middeleeue behoorlik bekyk (Kümmel 1973:13-19).

Binne die raamwerk van die Roomse Kerk kon die humanisme geen egte historiese kritiek van die Nuwe Testament aan die gang sit nie, maar die teologie van die Reformasie het drie fundamentele dinge opgemerk, hoewel die konsekwensies daarvan eers veel later begin duidelik word het.

Die genoemde drie insigte is:

(a) Dit is nie die kerk en die pous wat die sin van die Heilige Skrif kan vasstel nie, maar die Skrif moet deur die Skrif self verklaar word (vgl. Luther). Nou word die Bybelse eksegese beskou as die belangrikste taak van alle teologiese arbeid.

(b) 'n Teks het nie 'n viervoudige betekenis soos in die vroeë kerk gemeen is nie, maar net een letterlike betekenis.

(c) Sy kennis van die dispuut wat in vroeër eeue oor die outeurskap van bepaalde Nuwe-Testamentiese geskrifte bestaan het, lei Luther daartoe om teologiese kritiek teen byvoorbeeld Hebreërs, Jakobus, Judas en Openbaring te lewer.

In 1567 verskyn die eerste metodologiese ondersoek na die korrekte interpretasie van die Skrif, naamlik Matthaeus Flacius Illyricus se "Sleutel tot die Skrifte". Dié werk wys die weg na 'n werklik historiese benadering tot die bestudering van die Bybelse tekste.

Tog is ' $n$ egte historiese benadering tot die Nuwe Testament onmoontlik gemaak weens die volgende twee belangrike (foutiewe?) vooronderstellings:

(a) Die Bybel moet as 'n eenheid verstaan word; die skynbare teensprake berus op ' $n$ verkeerde verstaan van die tekste.

(b) Die toets vir die regte uitleg van ' $n$ teks, is of dit ooreenstem met die geloof ("analogia fidei") - vgl. Rm 12:6.

Joachim Camerarius se kommentaar op geselekteerde gedeeltes van die Nuwe Testament (1572), is baie belangrik, omdat hy die Skrifgedeeltes in die lig van hul eie tyd probeer verklaar en nié aan die hand van die kerkvaders se uitsprake nie.

Die ietwat latere Grotius en Lightfoot het die kennis aangaande die geskiedenis van die Nuwe-Testamentiese tyd geweldig laat vermeerder, maar hulle kon nòg by die ortodokse Protestante nòg by die Roomse teoloë die volkome onhistoriese benadering deurbreek. Nuwe basiese gesigspunte was nodig om 'n deurbraak in hierdie rigting moontlik te maak (Kümmel 1973:20-39).

In 1514 is vir die eerste keer 'n Griekse teks van die Nuwe Testament gepubliseer. Dit was in Spanje. Twee jaar later, in 1516, is die 
teks van Erasmus in Basel gepubliseer. Hoewel Erasmus se teks nie baie noukeurig nie en boonop uit swak manuskripte saamgestel was, het dit wye aandag geniet. Vanaf die middel van die 16de eeu is dit herhaaldelik herdruk.

\section{VANAF DIE SEWENTIENDE EEU TOT DIE BEGIN VAN DIE AGTIENDE EEU}

Sedert 1633 is die Textus Receptus nie meer verander nie en later het sekere Protestantse teoloë dit as geïnspireerd en ongeskonde beskou.

In die publikasies van die Franse priester Richard Simon sedert 1678 , word vir die eerste keer kritiese metodes aangewend in ' $n$ historiese bestudering van die oorsprong van die tradisionele vorm van die Nuwe-Testamentiese teks en van die vraag na die regte verstaan van die Nuwe Testament: In 1689 verskyn sy "Kritiese geskiedenis van die teks van die Nuwe Testament", kort daarna gevolg deur die kritiese geskiedenis van die vertalings van die Nuwe Testament (1690) en die "Kritiese geskiedenis van die vernaamste interpreteerders van die Nuwe Testament" (1693). So lewer hy 'n belangrike bydrae tot die ontstaan van die wetenskap van die tekskritiek. Tog word hy deur dogmatiese vooronderstellings verhinder om die historiese gevolgtrekkings te maak wat deur sy waarnemings vereis word.

Ná Simon se werk verskyn dié van John Mill gevolg deur dié van Johan Albrecht Bengel wie se uitgawe van die Griekse Nuwe Testament in 1734 verskyn het met 'n uitgebreide kritiese apparaat daarby. Ook Johann Jacob Wettstein, 'n tydgenoot van Bengel, publiseer ' $n$ belangrike kritiese uitgawe van die Griekse teks van die Nuwe Testament en pleit openlik dat die Nuwe Testament soos enige ander geskrif vanuit sy tyd en met die oë van sy oorspronklike lesers gelees moet word.

Ten spyte van al hierdie impulse het dit nog nie sover gekom dat die Nuwe Testament voluit histories benader is nie, dus as "a witness out of the past to the process of historical development" nie. Hierdie houding het vir die eerste keer te voorskyn getree in die loop van die Engelse deïsme se kritiese bestudering van die godsdiens.

Die streng historiese bestudering van die Nuwe Testament as ' $n$ aparte identiteit in onderskeid van die Ou Testament, het begin met die deurbraak van JS Semler en JD Michaelis in die tweede helfte van die 18de eeu. Dit het in die eerste plek uitgeloop op die ernstige bestudering van die literêre probleme in die Nuwe Testament. Dit het gepaard gegaan met' $n$ analise van die geskiedenis van die vroeë 
Christendom en van die denke van die vroegste Christene (Kümmel 1973:40-74).

\section{DIE TYDPERK VAN DIE HISTORIES-KRITIESE ONDERSOEK}

Die eerste geleerde wat die geskrifte van die Nuwe Testament konsekwent histories-krities benader het, was FC Baur (1792-1860). Hy wou vasstel wat die strekking van die mededelinge van die verskillende beriggewers was en het daarna gestreef om verbande en ontwikkelinge in die geskiedenis van die vroeë Christendom te ontdek. Daarby het hy uitgegaan van die teenstelling tussen Paulus en Petrus volgens 1 Kor 1:12, waar volgens hóm die wagwoord van vier groepe gehoor word: (1) Ek is van Paulus, (2) Ek is van Apollos, (3) ... Sefas, (4) ... Christus.

Vir Baur is die geskiedenis 'n botsing van meninge wat lei tot 'n vollediger insig. Hý is baie krities oor die historiese betroubaarheid van die evangelies.

Baur se werk dui onder andere aan dat ' $n$ wetenskaplike bestudering van die geskrifte van die Nuwe Testament vanuit enige filosofiese of dogmatiese vooronderstellinge waaroor gediskusseer kan word nie, sedert die opkoms van die histories-kritiese benaderingswyse onmoontlik is (De Jonge \& Van Duyne 1980: 30-2).

\subsection{Literêre kritiek}

Met "literêre kritiek" word gewoonlik bedoel die bestudering van 'n teks as literêre verskynsel, met gebruikmaking van alle middele wat die literatuur-wetenskap ten dienste staan by die ontleding van vorm en inhoud.

In die Nuwe-Testamentiese wetenskap word die term egter gewoonlik slegs gebruik vir die ontleding van die wordingsgeskiedenis van ' $n$ teks. So is literêre kritiek dan in hoofsaak bronnekritiek. 'n Treffende voorbeeld hiervan is die studie van die Sinoptiese Evangelies wat vir ' $n$ lang tyd nie die nadruk gelê het op die evangelies as literêre eenhede nie, maar as besonder ingewikkelde versamelinge van materiaal van allerlei herkomste en van verskillende betroubaarheid (De Jonge \& Van Duyne 1980: 32v).

Die doel van hierdie ontleding van die Sinoptiese Evangelies was om so ver as moontlik in die verlede te gaan; daar is gepoog om die oudste elemente in die oorlewering te onderskei, hul betroubaarheid te toets en met behulp daarvan die lewe van Jesus te rekonstrueer. Ook is gepoog om vas te stel wat Jesus regtig geleer het en wat in die evangelies aan sy volgelinge toegeskryf moet word. (Vir voorbeelde van literêre kritiek, vlg. De Jonge \& Van Duyne 1980:34.)

Miskien is die grootste fout van die literêre kritiek dat nie genoeg 
erns gemaak is met die eenheid van vorm en inhoud en met die samehang van die geheel nie (De Jonge \& Van Duyne 1980: 33-66).

Weens die gebreke van die literêre kritiek, word dit gevolg deur die vormondersoek, die tradisie-ondersoek, redaksie-ondersoek en die struktuuranalise wat hierna ter sprake sal kom (De Jonge \& Van Duyne 1980:35).

\section{2 "Formgeschichte" (Vormondersoek)}

Sedert die twintigerjare van hierdie eeu het die sogenaamde "Formgeschichte" veel opgang gemaak. Wat die Nuwe Testament betref was die Duitse geleerdes, Martin Dibelius, Rudolf Bultmann en KL Schmidt, die grondleggers van hierdie metode. 'n Mens kan sê dat RH Lightfoot en Vincent Taylor die metode aan die Engelse bekend gestel het, terwyl die Amerikaners dit by BS Easton en FC Grant geleer het (Hunter 1951:37; Koch 1974:3-7).

Hierdie mense was baie geïnteresseerd in die preliterêre, mondelinge vorme waarin die stof wat in die evangelies gebruik word, bestaan het en oorgelewer is (vgl. ook De Jonge \& Van Duyne 1982:42).

Volgens Hunter (1951:37) begin die "Formgeschichte" met een groot vooronderstelling, naamlik dat die evangelieverhale- en uitsprake in die tydperk van mondelinge oorlewering (sê ongeveer 30-60 n.C.), mondeling en as aparte eenhede ("pericopae") in die verskillende Christelike gemeenskappe in omloop was.

Hierdie ondersoek hou hom besig met die patrone of vorme wat die verhale aangeneem het en met die redes waarom dit bewaar is. Die doel is om ons agter alle dokumente terug te voer na die vroegste tradisie aangaande Jesus.

Wanneer iemand 'n verhaal oor-en-oor vertel of 'n verklaring maak, ontwikkel hy later 'n soort tegniek. Hier kan gedink word aan 'n ou ballade, 'n maatskaplike werker se verslagboek of 'n geregsdienaar se verklaring in die hof. So kan die deskundiges oor volksliteratuur verhale volgens hul vorm klassifiseer: die manier waarop die verhale begin, die hoeveelheid detail wat dit bevat, die wyse waarop dit eindig. Volgens die vormondersoekers (of vormkritici) kan die verhale en uitsprake in die evangelies op soortgelyke wyse geklassifiseer word en kan skerpsinnig geraai word waarom hulle bewaar is (vgl. Hunter 1951:37).

Die "formgeschichtliche" ondersoek (vormondersoek) geskied in verskillende fases (Hunter 1951:37v):

\section{Eerstens:}

Klassifisering van die evangeliemateriaal. Oor die algemeen word 
vier soorte materiaal in die tradisie gevind, naamlik (verskillende geleerdes gebruik verskillende terme om dieselfde vorme aan te dui):

(1) Kort verhale met weinig deskriptiewe besonderhede, wat uitloop op 'n gedenkwaardige uitspraak van Jesus. Dit heet paradigmas of uitspraakverhale ("pronouncement stories").

(2) Meer breedvoerige vertellinge waarin ' $n$ wonderwerk van Jesus ter sprake kom (wondervertellinge), byvoorbeeld Die storm op die meer (Mk 4), Die dogtertjie van Jaïrus (Mk 5), Die seun wat aan epilepsie gely het (Mk 9).

(3) Woorde van Jesus wat onderverdeel word in wysheidswoorde, profetiese woorde, kerkwoorde, gelykenisse, ensovoorts.

\section{Tweedens:}

Herwinning of vasstelling van die oorspronklike vorm van genoemde materiaal.

Daar word aanvaar dat die verhale en uitsprake, soos dit gewoonlik met tradisies gebeur, verandering ondergaan en toevoegings gekry het en dat redakteurs ook 'n rol gespeel het. So sou Markus byvoorbeeld baie van die verbindingsmateriaal in sy evangelie verskaf het. Markus 10:46 ("Daarna kom hulle in Jerigo aan") is 'n voorbeeld daarvan. Om vas te stel hoe die perikope in die mondelinge fase daar uitgesien het, moet sulke latere toevoegings verwyder word.

\section{Derdens:}

Vasstelling van die "Sitz Im Leben".

Vervolgens moet vasgestel word waar hierdie perikope in die vroeg-Christelike tradisie tuisgehoort het en wat hulle funksies daar was. Die "Sitz im Leben" van byvoorbeeld die gelykenisse of die wondervertellinge moet dus vasgestel word.

Volgens die vormnavorsers het biografiese motiewe geen noemenswaardige rol gespeel by die bewaring van die tradisie wat ons in die evangelies teenkom nie. Vir die vroeë Christene sou dit gegaan het om ' $n$ behoefte aan verhale oor Jesus met die oog op prediking en propaganda. Weens opposisie was daar' $n$ behoefte aan apologetiese stof en hulle het gesaghebbende leiding gesoek oor allerlei probleme in verband met die Christelike geloof en lewe. Hierdie behoeftes het dan gelei tot die bewaring en vorming van die evangelietradisie (vgl. Hunter 1951:31-8).

Te oordeel aan die "Formgeschichte" (vormnavorsing) is ons kanonieke evangelies dus die eindproduk van 'n evolusionele proses (vgl. Vorster 1981: 10-12).

Wat die materiaal in die evangelies betref, word daar drie verskillende "Sitze im Leben" onderskei, naamlik: 
(1) Die werksaamhede van Jesus (die "Sitz im Leben Jesu").

(2) Dié in die vroeë kerk voordat die evangelies op skrif gestel is (die "Sitz im Leben der alten Kirche").

(3) Dié waarin die evangeliste die oorgelewerde tradisies gekontekstualiseer het (die "Sitz im Leben Ecclesiae"- trouens soos vermeld deur Van Aarde 1982: 22; Smalley; 1977:182).

Die tradisionele tradisie- en vormondersoek het hoofsaaklik op die "Sitz im Leben" in die vroeë kerk gekonsentreer. Volgens Zimmermann (1974:173) word die besondere situasies binne hierdie tradisielaag gewoonlik gekategoriseer as "die Verkündigung der Frohbotschaft, den christlichen Gottesdienst und die christliche Glaubensunterweisung". Van Aarde (1982: 22) noem dit: kerugma, liturgie en kategese". (Vir breedvoeriger bespreking van die "formgeschichtliche" metode, vgl. Zimmermann 1970:128-213.)

\section{3 "Traditionsgeschichte" (Tradisie-ondersoek)}

Volgens Hauck (1969:166) is hierdie ondersoek gerig op die vraag na die "Konzeption u(nd) Motiven der Sammler von Einzelüberlieferungen zu einheitlichen Texten".

Die volmondersoek het 'n klompie vrae laat ontstaan waarop dit self geen antwoorde kon verskaf nie: die vraag byvoorbeeld hoe 'n enkele sage sy weg tot ' $n$ versameling sages gevind het en daarna tot 'n "brongeskrif". Ook die vraag hoe die "brongeskrif" met ander geskrifte kon saamgroei tot die huidige boek of boeke, en die probleem hoe verskillende "brongeskrifte" uiteindelik een gemeenskaplike ontwerp ("Aufriss") kon vertoon (vgl. Kaiser et al 1969:23-4; De Jonge \& Van Duyne 1982:42-3; Catchpole 1977:165-80).

Waar die literêre kritiek dus vra uit watter bronne 'n geskrif saamgestel is, vra die tradisie-ondersoek hoe dit gebeur het dat hierdie bronne gebruik is vir die tot stand bring van die huidige geskrif.

\section{4 "Redaktionsgeschichte" (Redaksie-ondersoek)}

Waar die vormondersoek gevra het in watter situasie en met watter doel ' $n$ bepaalde vorm ontstaan het, en die tradisie-ondersoek probeer vasstel het waarom en op watter manier materiaal wat dieselfde vorm het by mekaar gevoeg is en waarom en op watter manier verskillende versamelings saamgevoeg is tot 'n "brongeskrif" of -geskrifte, daar kom die redaksie-ondersoek met sy eie vrae. Die redaksie-ondersoek vra byvoorbeeld wat die volle omvang van die 
evangeliste se skeppende bydrae was toe hulle met behulp van die oorgelewerde materiaal elkeen 'n evangelie geskryf het.

Watter spore van hul vormgewende arbeid kan in die evangelies uitgewys word? Wat wou hulle met hul werk bereik? Dit gaan dus om die vraag wat gebeur het in die finale fase van die samestelling van die evangelies.

Deur ' $n$ aantal uitsprake van Jesus en 'n aantal verhale oor Hom op 'n bepaalde manier te bewerk, op mekaar te laat volg en deur middel van eie opmerkings te verbind, probeer elke evangelis die betekenis van Jesus se woorde en dade vir 'n bepaalde lesersgroep duidelik maak (vgl. De Jonge \& Van Duyne 1982: 60; Smalley 1977: 181).

Die redaksie-ondersoek word gedoen deur noukeurig te let op die individuele opmerkings van die evangeliste, hul redaksionele skakels en opsommings; verder word gelet op die seleksie, modifikasie en uitbreiding van die stof wat hulle gebruik. Wanneer Matteus of Lukas byvoorbeeld met Markus vergelyk word, is dit moontlik om te ontdek hoe elke outeur hierdie tradisie wat hy ontvang het, verstaan en geïnterpreteer en meermale geredigeer het (Smalley 1977: 183; Van Aarde 1982: 28-38; vgl. ook Van Aarde vir die vraag of die redaksie-ondersoek in ' $n$ kontinue of diskontinue verhouding tot die vorm-en tradisie-ondersoek staan).

Reeds by die vormondersoek het die belangrikheid van die vorm ter sprake gekom. Die vorm bepaal in 'n groot mate die inhoud: 'n Skrywer of verteller wil ' $n$ bepaalde boodskap goed by ' $n$ bepaalde groep lesers tuisbring. Daarvoor kies hy onder andere ' $n$ bepaalde vorm om langs dié weg die kans te verbeter om in sy doel te slaag.

Wie die Nuwe Testament reg wil verstaan, moet van hierdie dinge bewus wees en met alle beskikbare hulpmiddele probeer vasstel met watter soort verhaal, spreuke, opsomming, ensovoorts hy te doen het èn waarom daardie vorm gekies is. Dit help om agter te kom wat die skrywer wil sê en wat hy nie wil sê nie.

Wanneer Markus byvoorbeeld van die besetene van Gerasa vertel (Mk 5: 1-20), draai die verhaal om die man wat genees is, om Jesus wat genees het en om die reaksie van die mense. Wat met die verdrinkte varke gebeur het, is nie ter sake nie. Die vraag waarop die leser moet antwoord, is hoe hý op Jesus reageer, wat hý van Hom verwag en wat hý vir Hom oor het.

Ook die plek wat ' $n$ verhaal of 'n bepaalde uitspraak in die teks as geheel inneem, is belangrik. Selfs die kleinste besonderheid is belangrik as onderdeel van 'n groter geheel (vgl. De Jonge \& Van Duyne 1982: 161; Van Aarde 1982: 128-38).

Dit is in beginsel moontlik om te onderskei tussen redaksie-ondersoek as die bestudering van die waarneembare veranderinge wat deur die evangelieskrywers aangebring is aan tradisies wat hulle ontvang en gebruik het, en die komposisie-ondersoek wat konsen- 
treer op die rangskikking van hierdie materiaal. Op die oomblik word die saak wat by die komposisie-ondersoek die belangstelling wek, egter in die reël as deel van die redaksie-ondersoek gehanteer (Smalley 1977: 181).

\section{5 "Gattungen" (Genres) in die Nuwe Testament}

Die evangelienavorsing hang nou saam met die vraag tot watter "Gattung" of literêre genre die evangelie behoort. Volgens Van Aarde (1982: 3) kan 'n literêre genre gesien word as 'n geheel-teks wat op sy beurt bestaan uit woorde in sinne en sinne in 'n perikoop en perikope in die teks as geheel, (deur Talbert die "holistiese konteks" genoem.) Elke onderdeel moet in sy onmiddellike konteks geïnterpreteer word. Die literêre identifisering van 'n teks kan help om vas te stel wat die boodskap van die teks is: Wie ' $n$ troukaartjie ontvang, verwag nie om 'n doodsberig daarin te lees nie!

'n Mens kan sê dat 'n genre of "Gattung" 'n kollektiewe kategorie van literêre eenhede is wat gemeenskaplike eienskappe in vorm en inhoud vertoon (Van Aarde 1982: $4 \mathrm{v}$ ).

Volgens Zimmerman (1970: 140) het 'n "Gattung" die volgende wesenlike kenmerke:

(a) Dit staan na aan die tradisie.

(b) Dit is verkondiging in die vorm van ' $n$ historiese uiteensetting.

(c) Dit het 'n aktuele toepassing ("Bezug").

Gewoonlik word daar in die Nuwe Testament vier literêre "Gattungen" of genres onderskei, naamlik evangelie, brief, historiese monografie en apokalips (Conzelmann \& Lindemann 1980: 31; Zimmermann 1970: 135-44).

Die groter vorme, naamlik die "Gattungen", bevat kleiner vorme byvoorbeeld praktiese woorde, wysheidswoorde, wetswoorde, gelykenisse, strydgesprekke, wonderverhale, ensovoorts (Zimmermann 1970: 144-69) en formules soos homologie, geloofformule en doksologie (Zimmermann 1970: 169-72).

Uit die noue samehang tussen vorm en inhoud en die hulp wat die vorm verleen vir die verstaan van 'n teks, vloei voort dat die identifisering van die "Gattungen" en vorme belangrik is vir die verstaan en toepassing van die boodskap van die evangelies.

Die genre-ondersoek kan met behulp van verskillende "metodes" geskied, byvoorbeeld (vgl. Van Aarde 1982: 7 vv):

(a) Dit kan so gedoen word dat dit uitmond in literêre identifisering en klassifisering en die sinkroniese vergelyking met ander genres.

(b) Bogenoemde vergelyking kan ook diakronies wees deur histo- 
ries-krities die historiese wording van tekste te ondersoek. Voorbeelde is die tradisie- en "formgeschichtliche" benadering in die Bybelwetenskappe.

(c) Literêre identifisering kan ook oorgaan in die vraag na die "Sitz im Leben" van die betrokke genre èn na die verhouding van die buitekontekstuele "Sitz im Leben" tot die binnekontekstuele "Sitz in der Literatuur", met die doel om die literêre funksie van die betrokke genre te bepaal.

(d) Die genre-ondersoek kan ook aangewend word vir die interne analise van die materiaal van 'n spesifieke teks. Hierdie interne analise kan onder andere insluit: analise van skrywersgesigspunte, lesersverwagtinge, gebruikmaking van bronne, formele struktuur, karakterisering, aktante- en sekwensiefunksies, ensovoorts.

By die genre-ondersoek gaan dit dus nie net om ondersoek na vorm en inhoud nie, maar ook na fyner besonderhede met betrekking tot vorm en inhoud.

Wanneer hier na "genre" verwys word, word gedink aan wat genoem word die "poëtiek" van 'n teks. (Die term "poëtiek" is hier 'n afleiding van die Griekse woord poieîn (vgl. Van Aarde 1982:7).

Vervolgens word slegs kortliks verwys na twee verskillende modelle wat gebruik word om vas te stel tot watter literêre genre 'n evangelie behoort: Die een is 'n evolusionistiese model, waarvolgens elke evangelie ontwikkel het uit'n klein nukleus wat geleidelik gegroei het. Die ander is 'n analogie-model, dit wil sê die skrywers van die evangelies het 'n bestaande literatuursoort as voorbeeld vir hul eie geskrifte geneem (Vorster 1981: 10-29). Volgens sommige is die voorbeeld van ' $n$ Ou-Testamentiese geskrif soos Eksodus geneem en volgens ander was die voorbeeld 'n tipe uit Hellenistiese literatuur, soos 'n biografie of 'n tragedie.

\subsection{Beperkinge van die histories-kritiese ondersoek}

In 1951 het Hunter wat nie sonder waardering vir die vormondersoek is nie, die kritiese opmerking gemaak dat die vorm waarin 'n verhaal vertel word, nooit vir ons kan sê of die hoofsaak ("substance") van die verhaal waar of vals is nie. Syns insiens kan die vormondersoek uit die aard van die saak nooit so objektief soos die bronne-ondersoek wees nie (Hunter 1951: 40).

Wat die redaksie-ondersoek betref, skryf Smalley (1977: 191), nader aan ons eie tyd, dat dit as metode om die evangelies te bestudeer, die volgende nadele het.

(a) Die tradisie-historiese kriteria waarop die redaksie-ondersoek normaalweg steun, is dikwels oop vir bevraagtekening weens 
dinge wat daardeur aanvaar word ("the assumptions involved in them").

(b) Te dikwels word aanvaar dat redaksie van die evangelies sou beteken dat daar "komposisie" in die sin van uitvinding deur die evangelis plaasgevind het - dit is nog nie bewysbaar nie.

(c) Redaksie-ondersoekers is by tye te subtiel en subjektief in hul benadering tot die evangelies, en in hulle beoordeling van die evangeliste se motiewe en metodes.

Syns insiens word versigtigheid benodig by die analise van enige redaksionele aktiwiteit, veral wanneer ons soos in die geval van die evangelies, nie altyd seker is wie die redakteur is of wat die presiese aard van die bronne is nie.

Hoewel redaksie-ondersoek noodsaaklik is vir alle ernstige bestudering van die evangelies, moet dit versigtig gebruik word. Dit is nie ' $n$ kwessie van redaksie of geskiedenis in die Nuwe Testament nie, maar van albei. As dít aanvaar word, sê Smalley, kan die "Redaktionsgeschichte" 'n positiewe hulpmiddel wees vir die verstaan van die vier evangelies en die intelligente gebruik daarvan vir Christelike prediking en onderrig. Deur hierdie metode kan lig gewerp word op die, erns van die hele saak, naamlik die oorspronge van die Christendom self (Smalley 1977: $191 \mathrm{v}$ ).

In 'n pas verskene publikasie getitel Van tekst tot uitleg. Luisteroefeningen in het Nieuwe Testament, merk De Jonge \& Van Duyne (1982: 37-41) onder andere op dat die histories-kritiese metode hom rig op die analise van tekste en ander histories-bruikbare materiaal (bv. argeologiese gegewens) en dat dit in die proses op leemtes en onduidelikhede stuit. Aangesien baie dinge onbekend is moet die historikus onvermydelik van korrigeerbare hipotetiese rekonstruksies gebruik maak.

Die histories-kritiese benadering van die verlede is volgens dieselfde outeurs, onvermydelik gebonde aan die voorstellingsvermoë van die historikus. Volgens hulle kan 'n mens op historiese gebied slegs waarskynlikheidsoordele vel.

Hulle gaan voort en sê dat die historiese ondersoek moeite het met die unieke, die onvergelykbare en dat dit ten slotte slegs as uitsondering "verklaar" kan word. Dit kan konstateer dat bepaalde tekste uitgaan van die moontlikheid van ' $n$ ingrype van God in die geskiedenis en dat hulle getuig van so 'n ingryping, byvoorbeeld die opstanding van Jesus Christus. Die histories-kritiese metode kan egter nie dan self konkludeer en sê God hét aantoonbaar ingegryp nie. Nie alleen die unieke nie, maar ook die prinsipieel-unieke is vir die histories-kritiese metode nie grypbaar nie.

De Jonge van Van Duyne stel ook die vraag of die histories-kritiese benadering nie 'n blokkering kan wees vir die luister na tekste 
wat self ' $n$ ander visie op die geskiedenis het en wél ruimte laat vir ' $n$ ingrype van God en van daaruit die menslike gebeure interpreteer nie.

' $n$ Ander probleem is egter dat ' $n$ prinsipiële openheid vir die unieke en die Unieke, op sý beurt kan lei tot 'n onkritiese vereenselwiging van menslike en Goddelike spreke en handeling.

De Jonge en Van Duyne (1982: 41) konkludeer dan dat ons die histories-kritiese metode nie mag (en kan) afskaf nie, maar dat ons moet bly soek na ' $n$ vollediger interpretasie van die Nuwe Testament, ook (en veral) deur gelowiges vír gelowiges, vir wie hierdie geskrifte ' $n$ besondere gesag het.

Du Toit (1980a:276) redeneer ongeveer in dieselfde gees as hy sê dat die historiese ondersoek oor die vraag na die "historiese Jesus" en die "verkondigde Christus" van die evangelies moet voortgaan, maar dat die vermoë van die historiese ondersoek om uitsluitsel oor sake te gee, beperk is. Dit kom by 'n grens waar net die geloof kan beslis.

Die aanwysbare beperkinge van die histories-kritiese metode het daartoe aanleiding gegee dat na ander metodes gesoek is wat die vrae kon beantwoord waarop die histories-kritiese metode nie 'n bevredigende antwoord kon gee nie. Per slot van sake is die geskiedenis van die teks nie gelyk aan die bedoeling van die teks nie; die geskiedenis moet by die bestudering van die teks ter sprake kom, maar waar en hoe?

\section{NUWE ONTWIKKELINGS}

\subsection{Inleiding}

Aangesien in die ander referate breedvoerige aandag geskenk sal word aan 'n paar van die belangrikste nuwe ontwikkelinge op die terrein van die Nuwe-Testamentiese metodeleer, beperk ons ons hier bykans tot die blote noem van enkeles.

Terwyl die vorige metodes hoofsaaklik histories en dus diakronies van aard is, het die belangstelling by baie die afgelope jare verskuif na die sogenaamde sinkroniese of strukturele metodes; dit is metodes wat kyk na die samestelling, die sogenaamde poëtiek van die teks.

Dit is bekend dat dit veral Ferdinand de Saussure was wat met die onderskeiding tussen diakronie en sinkronie in die literatuurwetenskap begin het (Van Aarde 1982:31).

By 'n diakroniese benadering tot ' $n$ teks soos dit by die historieskritiese metode gedoen word, word die teks as ' $t$ ware gehanteer soos 'n venster waardeur die ondersoeker na die "werklike" wêreld kan kyk. By die sinkroniese benadering daarenteen word die teks 
gehanteer soos 'n spieël wat die "vertelde" wêreld weerspieël (vgl.

Petersen 1978:19,24). By 'n sinkroniese of teksimmanente uitleg word gepoog om vas te stel wat die teks in sy huidige vorm wil sê. Die antwoord op die vraag word dan gesoek deur die teks as geheel te bestudeer en die samehang tussen die onderdele te probeer ontdek, terwyl elke onderdeel in samehang met die groter geheel, soms die "holistiese konteks" genoem, geïnterpreteer moet word.

In die evangelienavorsing het die oorgang vanaf die historieskritiese teksteorie na 'n teksimmanente teorie nie meteens plaasgevind nie. Op die oomblik is die navorsing nog in 'n oorgangsfase (Van Aarde 1982:25,27).

\subsection{Die vertellersperspektief-analise}

Die sogenaamde vertellersperspektief-analise speel 'n groot rol in die literatuur-teoretiese benadering wat bekend is as die Russiese Formalisme en die Amerikaanse New Criticism (Van Aarde 1982:35). Geleerdes soos Vorster (1978:116-9, 126-53) het dit in die Markusnavorsing benut en Van Aarde (1982:35) meen dat hierdie metode die bruikbaarste is vir die ondersoek na die verhaalstruktuur van verteltekste soos die evangelies. Syns insiens laat dit die meeste reg geskied aan die funksies wat die konstituerende prinsipes van 'n vertelling vervul om die interrelasies in die verhaalstruktuur tot uitdrukking te bring (Van Aarde 1982:35). Hierin sluit Van Aarde aan by Petersen wat sê: "The rhetoric of point of view, once we know how to look for it ...., is the best tangible device we have to help us teach ourselves to listen to what the narrator is telling us" (aangehaal deur Van Aarde 1982:35).

\subsection{Struktuur- en redevoeringanalise}

Die Suid-Afrikaanse struktuur- en redevoeringsanalise is nie op 'n hermeneutiese model gebaseer nie, maar het alleen betrekking op teksbinding- en sameh ang (Van Aarde 1982:26). Dit is 'n metode om die formele struktuur bloot te lê. Om dit te kan doen, word die teks ingedeel in perikope, kolongroepe, kola en kommata (vgl. Louw 1976; 1973:101-18; Du Toit 1980b).

Wat die poëtiek van 'n evangelie betref, kan die analise 'n belangrike bydrae lewer deur die raamwerk aan te dui waarbinne die intrige of "plot" ontwikkel.

\section{HUIDIGE STAND VAN DIE ONDERSOEK}

Op die oomblik is daar hoofsaaklik drie metodologiese rigtings in 
die Nuwe-Testamentiese eksegese waarop ons die aandag wil vestig:

Die histories-kritiese metode in sy modernste vorm; veral toegepas in die Amerikaanse redaksie-kritiese benadering wat teks-interne besonderhede soos die unieke aanvang en slot van diskoerse, verandering in bewoording en orde van literêre eenhede analiseer (Van Aarde 1982: 24).

Die Franse strukturalisme wat in 'n groot mate die resultate van die histories-kritiese ondersoek ignoreer (Van Aarde 1982: 26, 27).

'n Analise van die vertelelemente in 'n evangelie, sonder om die historiese omstandighede te ignoreer waarin 'n evangelie ontstaan het, soos deur Van Aarde (1982: 30-7) in sy proefskrif bepleit.

\section{SLOTSOM}

Uit wat tot dusver gesê is, blyk ten oorvloede dat 'n sterk geloof en vrome bedoelings nie ' $n$ waarborg is dat die Nuwe Testament reg verstaan sal word nie. Wetenskaplike worsteling met die Nuwe Testament as deel van die Heilige Skrif bly absoluut noodsaaklik juis vir mense wat dit saam met die Ou Testament, "en hulle alleen", aanvaar "as heilig en kanoniek om ons geloof daarna te rig, daarop te grond en daarmee te bevestig" (NGB art. 5).

Die volmaakte metode om hierdie tekste te bestudeer en te verstaan is nog nie gevind nie en sal seker nie in hierdie lewe gevind word nie. Sonder die wetenskaplike metodes, ook die nuwes wat hier ter sprake kom, is daar egter 'n rykdom van insigte wat ons moeilik indien ooit op 'n ander manier sal verwerf. As dit vir ons onbekend bly, is dit tot ons eie skade en tot skade van hulle wat na ons prediking en pastorale leiding, moet luister.

Hierdie nuwe metodes moet sekerlik nie gesien word as 'n volkome plaasvervanging vir alle aanvaarde metodes van die verlede nie. Dit behoort egter met dankbaarheid benut te word as nuttige bykomende hulpmiddels om die boodskap van die boek van alle boeke duideliker te kan hoor (vgl. Kümmel: 405 v).

\section{ENKELE STELLINGS EN VRAE VIR VERDERE DISKUSSIE}

Die wetenskaplike bestudering van die Bybel is onnodig vir die geloofslewe en is selfs ' $n$ bedreiding vir die geloof.

Die dogmatiek en die eksegese het mekaar nodig. Hoe kan hulle mekaar tot hulp wees?

In die Nederduitsch Hervormde Kerk van Afrika besef die meeste predikante nog nie eens wat die konsekwensies van die historieskritiese metode vir die prediking is nie. 
Die nuwe eksegetiese metodes kan nie die histories-kritiese metodes vevang nie. Waarom nie?

Dink u dat die histories-kritiese metode nie aangevul hoef te word deur ander metodes nie, omdat dit in elk geval al die nodige antwoorde verskaf wat u vir u predikantswerk nodig het? Motiveer $u$ antwoord.

Die probleme en resultate van die teologiese wetenskap moet aan nie-teologies gevormde lidmate deurgegee word, juis om hulle beter toe te rus vir die toenemende aanslae teen die Christelike geloof.

\section{LITERATUURVERWYSINGS}

Bornkamm, G 1968. Jesus von Nazareth. 8. Auflage. Stuttgart: Kohlhammer.

Catchpole, DR 1977. Tradition history, in IH Marshall (ed). New Testament interpretation. Essays in principles and methods. Exeter: Paternoster, 165-80.

Conzelmann, H en A Lindemann 1980. Arbeitsbuch zum Neuen Testament. 5. Auflage. Tübingen: Mohr.

De Jonge, M en HMJ van Duyne 1982. Van tekst tot uitleg. Luisteroefeningen in het Nieuwe Testament. 's-Gravenhage: Boekencentrum.

Du Toit, AB 1980 a. Algemene inleiding tot die evangelies, in AB du Toit (red). Handleiding by die Nuwe Testament. IV Die Sinoptiese Evangelies en Handelinge: inleiding en teologie. Pretoria: NG Kerkboekhandel, 1-30.

Du Toit, AB 1980 b. Die historiese Jesus en die verkondigde Christus van die evangelies, in AB du Toit (red). Handleiding by die Nuwe Testament. IV. Die Sinoptiese Evangelies en Handelinge: inleiding en teologie. Pretoria: NG Kerkboekhandel, 255-81.

Du Toit, AB 1980 c. Die praktyk van eksegese in die lig van nuwere wetenskaplike ontwikkeling, in Die Nuwe-Testamentiese Wetenskap vandag. Departemente Nuwe Testament (A \& B) en Grieks, Universiteit van Pretoria, 119-36.

Hauck, F 1969. Theologisches Fach- und Fremdwörterbuch. 5. Auflage. München: Siebenstern.

Hunter, AM 1951. Interpreting the New Testament. 1900-1950. London: SCM.

Die drie formuliere van eenheid, s.a. in Die ekumeniese belydenisskrifte: Voorlopige proefvertaling van die interkerklike kommissie. s.1.: NG Kerkuitgewers.

Kaiser, $\mathrm{O}$ et al. 1969. Einführung in die exegetischen Methoden. 4. Auflage. München: Chr. Kaiser.

Koch, K 1974. Was ist Formgeschichte? Methoden der Bibelexegese. 3. Auflage. Neukirchen: Neukirchener Verlag.

Kümmel, WG 1973. The New Testament. The history of the investigation of its problems. (Translated by SM Gilmour \& HC Kee). London: SCM.

Louw, JP 1973. Discourse analysis and the Greek New Testament. Bible translator 24, 101-18.

Louw, JP 1976. Semantiek van Nuwe-Testamentiese Grieks. Pretoria: Beta.

Nederlandse Geloofsbelydenis, s.a. in Die ekumeniese belydenisskrifte: Voorlopige proefvertaling van die interkerklike kommissie. s.l.: NG Kerkuitgewers.

Petersen, NR 1978. Literary criticism for New Testament critics. Philadelphia: Fortress.

Smalley, SS 1977. Redaction criticism, in IH Marshall. New Testament interpretation. Essays in principle and methods. Exeter: Paternoster, 181-95.

Van Aarde, AG 1982. God met ons. Dié teologiese perspektief van die Matteusevangelie. Pretoria: Universiteit van Pretoria. (Ongepubliseerde DD-proefskrif).

Vorster, WS 1980 a. Die evangelie volgens Markus: inleiding en teologie, in AB du Toit (red). Handleiding by die Nuwe Testament. IV. Die Sinoptiese Evangelies en Handelinge: inleiding en teologie. Pretoria: NG Kerkboekhandel, 109-55.

Vorster, WS 1980 b. Nuwere ontwikkelinge op die gebied van die Markusnavorsing, 
in Die Nuwe-Testamentiese Wetenskap vandag. Departemente Nuwe Testament (A \& B) en Grieks, Universiteit van Pretoria, 15-32.

Vorster, WS 1981. Wat is ' $n$ evanglie? Die plek van die tekssoort evangelie in die literatuurgeskiedenis. Pretoria: NG Kerkboekhandel.

Zimmermann, H 1970. Neutestamentliche Methodenlehre. Darstellung der historisch-kritischen Methode. 3. Auflage. Stuttgart: Katholische Bibelwerk. 